Implementing Digital Competence Framework for Future Teachers' Professional Development

UDC [378.147:37.011.3-051]:004

\title{
IMPLEMENTING DIGITAL COMPETENCE FRAMEWORK FOR FUTURE TEACHERS' PROFESSIONAL DEVELOPMENT
}

\author{
Olena Beskorsa \\ Candidate of Pedagogical Sciences, Associate Professor of Primary \\ Education Theory and Practice Department \\ SHEE "Donbas State Pedagogical University" \\ Sloviansk, Ukraine \\ ORCID ID 0000-0001-8018-8549 \\ beskorsyhelen@gmail.com
}

\begin{abstract}
The mass implementation of digital technology in professional activity and everyday life causes increasing demands for training future teachers who are responsible for preparing the young generation to participate efficiently in modern society. Thus, the article reveals the relevant issue of future teachers' professional development through implementing digital competence framework. The development of teachers' digital competence is a target of a number of foreign and Ukrainian researchers. The theoretical determination of the concept "digital competence" and "digital literacy" are represented in works by D. Belshaw, P. Gilster, N. Hockly, N. Sonck, S. Livingstone, E. Kuiper and others. Terminological clarification of these concepts are highlighted in the researches of Ukrainian scientists (V. Bykov, L. Havrilova, O. Danylchuk, M. Zhaldak, A. Kolomiiets, O. Sysoieva, I. Smyrnov, O. Spirin and others).

The purpose of the paper is to present the theoretical justification of the digital competence framework for future teachers and in such a way to contribute to their professional development.

In this paper, the author proves that digital competence is a constituent part of professional competence. The structure of digital competence is characterized and visualized. It contains the following elements: ICT fluency; data, information and media literacy; digital self-development; communication, networking, participating; digital innovation and creation. The detailed analysis of European Framework for Digital Competence of Educators shows the elements of the competence, such as professional engagement, digital resources, teaching and learning, assessment, empowering learners, and facilitating learners' digital competence. The author emphasizes on the necessity to include the following element to the framework: motivation and positive self-perception, new methodologies for digital competence development. As they are essentioal for implementing digital technologies in educational process, as well as allows to establish indicators for evaluating the level of its development.

It is concluded that regarding to the different aspects of future teachers' digital competence, which we have expounded on in this paper, clearly reflects all the demands, which should be taken into consideration, while designing digital competence framework for educators in Ukraine according to educational reforming and upgrading process, as well as the relationship that must be established between the major components of teachers' digital competence.
\end{abstract}

Key words: digital competence; teachers' training; digital competence framework; professional development; digital technologies; new methodologies.

Problem setting in general. The increase of using technologies in various spheres of society and different fields of knowledge has started since the1980s. As a result, the concept of "information society" has been emerged. The new forms of 
Implementing Digital Competence Framework for Future Teachers' Professional Development

accessing, processing and storage of information cause the new ways of teaching, learning and generating knowledge.

The total digitalization of all the spheres of modern society has a great impact on the way people live, interact, communicate, learn and generate a new knowledge. So nowadays a person should acquire a certain amount of new knowledge and skills in order to participate efficiently in modern society. Such a situation poses the issue of what new skills a teacher should master to educate the young generation. In this context a new term "digital competence" immerged as a basic methodological skill which all future teachers should possess by the end of their study at university. It is generally thought that studying and technology must be combined in teacher's training.

The whole model of teaching and the curriculum could be altered with the help of understanding the strategic importance of technology and innovations. The strategic importance of providing digital education should be identified in pedagogical universities, because the skills of the teachers are reflected on the students. The teacher has to be able to integrate pedagogic skills with digital skills and utilize these skills in the practice. When the teacher has the competences to provide digital education, students can be able to exploit their knowledge in work life.

These new trends in teachers' training do not contradict the process of education modernizing in Ukraine and, in particular, the reforming processes of higher pedagogical education. So in the Concept of New Ukrainian School the tools for ensuring success in education are thought to be information and communication technology, being implemented into educational process. It is also pointed out in the Concept that one of the key competences in New Ukrainian school is digital one that includes confident and critical use and interaction with digital technologies for creating, searching, processing, and exchanging the information at work, in public space and in private communication [2].

Thus, the special framework for teachers must be worked out in Ukraine, taking into account the modern tendencies in all spheres of society and not contradicting the world practice of implementing information and communication technology into teachers' training.

The latest papers and publication on the problem. The theoretical determination of the concept "digital competence" and "digital literacy" are the targets of researches by D. Belshaw, P. Gilster, N. Hockly, N. Sonck, S. Livingstone, E. Kuiper and others.

To clarify the terminology, especially the difference between the concepts of "digital competence" and "digital literacy", we will briefly review their meaning. P. Gilster considers the digital literacy as basic skills concerning the access, assessment, and management of information related to learning processes. S. Covello suggests seven characteristic components of digital literacy: identifying training needs, accessing information in digital environments, using ICT tools (educational and communication technologies) to manage information, interpreting and representing information, evaluating information, and transmitting information. Later Y. EshetAlkalai clarifies that digital literacy covers more than the technical ability to use digital 
Implementing Digital Competence Framework for Future Teachers' Professional Development

devices, but it's regarded as a combination of technical and procedural, cognitive, and socio-emotional skills which are necessary for living, learning, and working in a digital society.

In some works, the concepts "digital literacy" and "digital competence" can have synonymous meaning, but we think that they have some differences. Having analysed a number of foreign and native theoretical studies of the concepts, we can conclude that the digital competence composes a range of literacies: technological, informational, audiovisual, and communicative.

According to R. Krumsvick, a teacher's digital competence includes a teacher's ability to implement ICT with the deep understanding of their didactic role in educational process, as well as comprehending the aims of various educational strategies and students' digital education [7, c. 68]. That means the teachers must make decisions on selecting electronic tools and features of their implementing in accordance with each educational situation. R. Krumsvik emphasizes that this ability should be developed while training future teachers at universities.

The general aspects of determination of the concepts "digital competence" and "digital literacy" are highlighted in the researches of Ukrainian scientists (V. Bykov, L. Havrilova, O. Danylchuk, M. Zhaldak, A. Kolomiiets, O. Sysoieva, I. Smyrnov, O. Spirin and others). L. Havrilova in her research makes a grounded analysis of the concepts "digital culture", "digital competence", "digital literacy" which gives us reasons to sum up that digital competence is wider in meaning than two other concepts and isn't limited by ability to implement digital media and ICT. However, the scientist claims that the concept "digital competence" need further clarifying and comprehending in the conditions of education modernization [1].

There is also a great number of researches that are devoted to different aspects of digital and information and communication competence of future teachers by H. Lavrentieva, R. Motsyk, O. Nikulochkina, L. Pietukhova, O. Sukhovitskyi, L. Sytnikova, V. Tataurov, O. Shyman, M. Shyshkina and others.

However, among such an amount of researches dedicated to developing teachers' digital competence and professional training, the issues of designing the digital competence framework for teachers are not still studied thoroughly, taking into account the conditions of reforming the educational system in Ukraine.

The objective of the paper is to present the theoretical justification of the digital competence framework for future teachers and in such a way to contribute to their professional development.

Theoretical basis of research. In the conditions of mass computerization and digitalization of all the aspects of life in modern society, New Ukrainian School includes implementing information and communication technologies in educational process, aiming at development of digitally literal personality at the $21^{\text {st }}$ century. Such a personality must be capable to understand the variety of media information and use it for making their own vital position. Today's students are surrounded by information from different sources, in particular media sources, most of them are English ones. 
Implementing Digital Competence Framework for Future Teachers' Professional Development

Access to the authentic electronic sources enlarges the learning content that is essential for getting knowledge or information, its storage and transference. That's why developing future teachers' digital competence contributes to creating, searching, processing and exchanging information in classes and after classes, as well as it is a constituent part of teachers' professional competence.

As the researchers from Canada's center for digital media and literacy claim, the digital competences in higher education contain six elements of digital capabilities. These competences consist of: ICT proficiency and fluency, information, media and data literacy, creating and innovating, digital research and scholarship, E-learning and professional development, communication, collaborating and participating as well digital identity and well-being. The skills of digital literacy and well-being are summarized in picture $1[6,3-4]$.

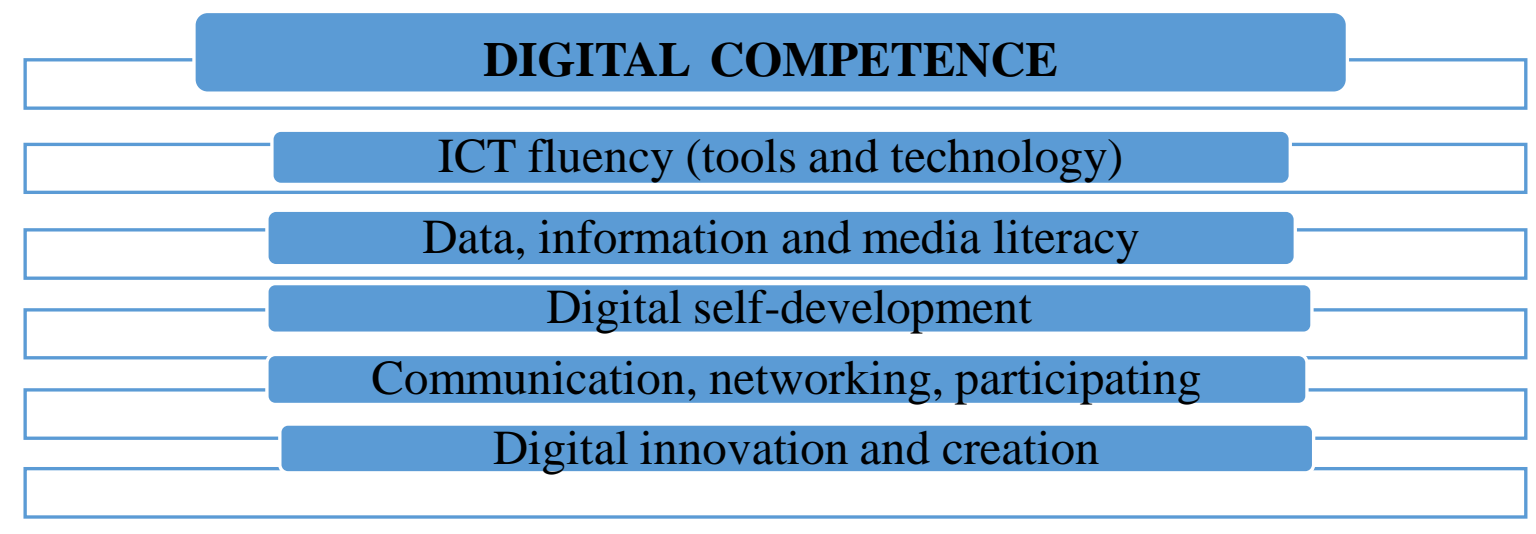

Pic. 1. The structure of digital competence

As we can see from the structure of digital competence, its current meaning necessarily includes the ability to use effectively tools and technology in different areas of personal life and work activity. M. G. Cervera emphasizes that digital competence like literacy cannot be separated from the social and educational needs to which the educational system must respond. Digital competence is claimed to involve a high degree of complexity due to its dynamic nature, both for its various levels of development as well as its constituents which can be represented as indicators to define and evaluate it. In light of this, it's clear that the digital competence is a main element of individual and professional development which the higher pedagogical education should integrate in order to ensure participation in 21st century society. So teachers must be capable of training personalities who can use ICT as an inherent component in their personal and social development [3].

In this regard it is necessary to design and develop training actions for future teachers that address digital competence. Having analyzed a number of reports and publications devoted to the problem of the massive use of ICT in the field of education, the need for digitally competent graduates of pedagogical institutions is obvious. The future teachers need a level of digital competence that will allow them to use technology effectively and appropriately. The sufficient skill level of the teachers in 
the digital realm is what we define as their 'digital competence', with regard to which various international institutions have proposed ICT standards (EPICT, 2006; ISTE, 2008; UNESCO, 2008) which organize the teachers' digital competence in the form of the knowledge and skills that the teachers should master in various areas. We agree with Krumsvick's approach which specifies that teachers' digital competence consists of four components: basic digital skills, instructional competence with ICT, and learning and training strategies and digital development [7].

It is proved that in the process of professional development for future teachers, approaches which are too focused on technical or instrumental aspects should be rejected in favour of training actions centered on the use of ICT at the educational level and for curricular development, while always remaining practice-oriented. Based on these standpoints, we can state that the 'instrumental-didactic' training of future teachers are essential to improving the attitude towards innovation with ICT.

Further thorough studying of the concept "digital competence" proves that it is a complex concept and there is a necessity to make a digital competence framework for teachers which must define knowledge, skills and abilities and can be used for defining learning results according to pedagogical education curriculum. This framework contributes to implementing new educational reforms through overcoming the contradictions between requirements of new educational standards, which concern using ICT in educational process, and absence of strictly defined requirements to the information and digital competence of a teacher [3].

In this paper we try to analyze European Framework for Digital Competence of Educators (DigCompEdu), adopted by European Commission and based on The Digital Competence Framework for Citizens, that is scientifically justified and contribute to understanding the definition "digital competence" in order to determine its correspondence to new educational standards in Ukraine. DigCompEdu should ensure the development of educators' professional competence and is designed for all educational stages, from early childhood to higher and adult education, including general and vocational education and training, special needs education, and non-formal learning contexts. $[4 ; 8]$.

In the context of reforming educational system in Ukraine this document is an essential benchmark. It was designed as a scientific project on the basis of collaboration and active interaction with a broad circle of people who are interested in digitalization of education and as a respond to a demand of the society to create a common framework benchmark that contributes to comprehending the concept "digital competence", taking into consideration the global processes and technology development. DigCompEdu is a tool for improving the educators' competence level in the sphere of digital technology, training and improving skills.

DigCompEdu is built in three spheres: professional competence, pedagogic competence, learners' competence. DigCompEdu details 22 competences organized in six areas (professional engagement; digital resources; teaching and learning; assessment; empowering learners; facilitating learners' digital competence). The focus 
Implementing Digital Competence Framework for Future Teachers' Professional Development

is not on technical skills. Rather, the framework aims to detail how digital technologies can be used to enhance and innovate education and training $[8,19]$.

As far as the context of this work is concerned, a detailed description of the constituents of digital competence framework is given below in order to establish quality indicators for carrying out the reflection process and evaluating the digital competence level.

According to DigCompEdu the sphere of professional competence is realized through teachers' ability to use digital technologies not only to enhance teaching, but also for their interaction with colleagues, learners, parents, as well as for their individual professional development and for the collective good and continuous innovation in the organisation and the teaching profession.

Pedagogic competence is claimed to extend four areas (digital resources; teaching and learning, empowering learners, assessment). There are loads of information that teachers can use in their professional activity. Teachers should identify the digital resources that fit their learning objectives, learning group and teaching style. One more demand for teachers is ability to develop digital resources themselves to support their teaching. At the same time, they must be aware of how to use and manage digital content responsibly. They have to follow copyright rules when using, modifying and sharing resources.

Digital technologies can contribute effectively to teaching and learning in many different ways. In the light of digital competence, teachers' goals are to design, plan and implement digital technology in different stages of the learning process. Assessment can also facilitate the innovation in education. Digitally-competent teachers should be able to use digital technologies within assessment, keeping in mind the main target - how to use digital technologies in order to enhance existing assessing strategies. At the same time, digital technologies can contribute to directly monitoring learner progress, to facilitating feedback and to allowing educators to assess and adapt their teaching strategies.

One of the key advantages of digital technologies is their capacity to transform the educational process into learner-centered strategy. In this relation digital technologies can be used to facilitate learners' active engagement. Digital technologies give also opportunity to support differentiation and independent learning offering activities that correspond to each individual learner's level of competence, interests and learning needs. Teachers should care about ensuring accessibility for all learners.

Learners' digital competence should be facilitated as an integral part of teachers' digital competence. In the document this sphere is believed to be aimed at developing learners' digital competence, digital communication and collaboration, creating new digital content, and solving digital (technical) problems [8].

But having analyzed the researchers' studies we can state that methodological part should be added to the sphere of pedagogic digital competence. As application of new methodologies for digital competence is essential. M. G. Cervera in his surveys also claims that digital competence is a kind of methodological skills. He points out that future teachers' readiness to apply new methodologies depends on their perception 
Implementing Digital Competence Framework for Future Teachers' Professional Development

on how their level of digital competence is developing while being trained and conducting teaching practice.

Their sense of ability or self-efficiency determines how they handle the challenges of taking on new goals with new methodologies. Positive self-perception regarding the increase in their teaching ability is crucial for achieving the level of effort and perseverance required by this innovative activity. So motivation and positive selfperception can help the future teachers to improve their professional awareness and positive attitude towards ICT development $[3 ; 5]$.

Taking into account the description of digital competence framework of educators and Ukrainian experience in the field of assessing and standardizing information and communication competence and digital one while training teachers, we should be guided by the following indicators: professional engagement; motivation and positive self-perception; new methodologies for digital competence development; digital resources; teaching and learning; assessment; empowering learners; facilitating learners' digital competence.

Providing future teachers' training based on above mentioned areas of digital competence allows to unify the demands to teachers' digital competence and establish its indicators. With regard to the framework it's clear that modern teachers are required a range of new knowledge while being digitally trained and know-how in the form of skills which they must acquire and develop in order to effectively participate in modern society. This process contributes to their constant professional and social development.

Conclusion and prospective for further research. To summarise, it should be noted that regarding to the different aspects of future teachers' digital competence, which we have expounded on in this paper, clearly reflects all the demands, which should be taken into consideration, while designing digital competence framework for educators in Ukraine according to educational reforming and upgrading process, as well as the relationship that must be established between the major components of teachers' digital competence. Following these aspects would make it possible to optimise processes of ICT integration into practice of teacher training from a didactic and methodological perspective and contribute to teachers' continuous professional development. Based on this premise, it is necessary to design and develop training plan for future teachers that address digital competence. We feel that these actions should be designed and developed to meet the institutional needs, motivated by the responsibility of having to train future generations for a digital society.

\section{REFERENCES (TRANSLATED AND TRANSLITERATED)}

1. Havrilova, L. \& Topolnyk, Ya. (2017). Digital Culture, Digital Literacy, Digital Competence as Modern Educational Phenomena. Informatsiini tekhnolohii I zasoby navchannia, 61(5), 1-14.

2. Concept "New Ukrainian school". (2016, October 27). Retrieved from http://mon.gov.ua/activity/education/zagalna-serednya/ua-sch-2016/konczepcziya.html

3. Cervera, M. G. \& Cantabrana, J. L. (2015). Professional development in teacher digital competence and improving school quality from the teachers' perspective: a case study. New approaches in education research, 2 (4), 115-121. 


\title{
O. BESKORSA
}

Implementing Digital Competence Framework for Future Teachers' Professional Development

4. Digital Competence Framework for Educators (DigCompEdu). (2018). Retrieved from https://ec.europa.eu/jrc/en/digcompedu

5. Dudney, G. Digital Literacy Primer. Retrieved from http://www.teachingenglish.org.uk/article/gavin-dudeney-digital-literacy-primer

6. Koskinen, J. (2015). Digital competence development teachers in Finnish higher education. Master's Thesis. Lahti, Finland: Lahti University of Applied Sciences.

7. Krumsvik, R. Situated learning and digital competence. Education and Information Technology. Retrieved from http://www.icicte.org/Proceedings2013/Papers202013/05-1Krumsvik.pdf.

8. Redecker, Ch. (2017). European framework for the digital competence of educators. Y. Punnie (Ed.). Luxembourg: Publications Office of the European Union.

\section{ВПРОВАДЖЕННЯ РАМКИ ЦИФРОВОЇ КОМПЕТЕНТНОСТІ ДЛЯ СПРИЯННЯ ПРОФЕСІЙНОГО РОЗВИТКУ МАЙБУТНІХ УЧИТЕЛІВ}

\author{
Олена Бескорса \\ кандидат педагогічних наук \\ доцент кафедри теорії і практики початкової освіти \\ ДВНЗ «Донбаський державний педагогічний університет» \\ м. Слов'янськ, Україна \\ ORCID ID 0000-0001-8018-8549 \\ beskorsyhelen@gmail.com
}

Анотація. Масове запровадження цифрових технологій у всі сфери життя змінює вимоги щодо підготовки майбутніх учителів, які є відповідальними за підготовку молодого покоління до взаємодії, спілкування, навчання та генерування нових знань у сучасному суспільстві. Тому в статті порушено актуальну проблему запровадження рамки цифрової компетентності майбутніх учителів 3 метою сприяння їхньому професійному розвитку. Питання формування цифрової компетентності вчителів $\epsilon$ предметом дослідження вітчизняних (В. Биков, Л. Гаврілова, О. Данильчук, М. Жалдак, А. Коломієць, О. Сисоєва, I. Смирнов, О. Спірін) та закордонних науковців (Д. Белшоу, Н. Хоклі, Н. Сонк, С. Лівінгстоун Р. Дж. Крумсвік).

Метою статті $є$ теоретичний аналіз рамки цифрової компетентності вчителів та вироблення показників сформованості цифрової компетентності. Автором доведено, що цифрова компетентність є складовою частиною фахової компетентності майбутнього вчителя. Наголошено, що до елементів рамки цифрової компетентності доцільно додати такі компоненти: мотивація і позитивне самосприйняття, а також запровадження нових методів та прийомів формування цифрової компетентності. Автор висновує, що рамка цифрової компетентності охоплює всі вимоги, враховуючи процеси реформування та модернізації освіти в Україні, сприяючи постійному професійному розвитку вчителів.

Ключові слова: цифрова компетентність; підготовка вчителів; рамка цифрової компетентності; професійний розвиток; цифрові технології; нові методики.

\section{СПИСОК ВИКОРИСТАНИХ ДЖЕРЕЛ}

1. Гаврілова, Л. і Топольник, Я. (2017). Цифрова культура, цифрова грамотність, цифрова компетентність як сучасні освітні феномени”, Інформаційні технології $i$ засоби навчання, 61(5), 1-14.

2. Концепція «Нова українська школа. (2016, 27 жовтня). Взято 3 http://mon.gov.ua/activity/education/zagalna-serednya/ua-sch-2016/konczepcziya.html 


\title{
O. BESKORSA
}

Implementing Digital Competence Framework for Future Teachers' Professional Development

3. Cervera, M. G. \& Cantabrana, J. L. (2015). Professional development in teacher digital competence and improving school quality from the teachers' perspective: a case study. New approaches in education research, 2 (4), 115-121.

4. Digital Competence Framework for Educators (DigCompEdu). (2018). Retrieved from https://ec.europa.eu/jrc/en/digcompedu

5. Dudney, G. Digital Literacy Primer. Retrieved from http://www.teachingenglish.org.uk/article/gavin-dudeney-digital-literacy-primer

6. Koskinen, J. (2015). Digital competence development teachers in Finnish higher education. Master's Thesis. Lahti, Finland: Lahti University of Applied Sciences.

7. Krumsvik, R. Situated learning and digital competence. Education and Information Technology. Retrieved from http://www.icicte.org/Proceedings2013/Papers202013/05-1Krumsvik.pdf.

8. Redecker, Ch. (2017). European framework for the digital competence of educators. Y. Punnie (Ed.). Luxembourg: Publications Office of the European Union.

\section{ВНЕДРЕНИЕ РАМКИ ЦИФРОВОЙ КОМПЕТЕНТНОСТИ ДЛЯ СПОСОБСТВОВАНИЯ ПРОФЕССИОНАЛЬНОГО РАЗВИТИЯ БУДУЩИХ УЧИТЕЛЕЙ}

\author{
Елена Бескорсая \\ кандидат педагогических наук \\ доцент кафедры теории и практики начального образования \\ ГВУЗ «Донбасский государственный педагогический университет» \\ г. Славянск, Украина \\ ORCID ID 0000-0001-8018-8549 \\ beskorsyhelen@gmail.com
}

Аннотация. Массовое внедрение цифровых технологий во все сферы жизни меняет требования к подготовке будущих учителей, ответственных за подготовку молодого поколения к взаимодействию, общения, обучения и генерирования новых знаний в современном обществе. Поэтому в статье рассмотрено актуальную проблему использования рамки цифровой компетентности будущих учителей с целью содействия их профессиональному развитию. Целью статьи является теоретический анализ рамки цифровой компетентности учителей и выработки показателей сформированной цифровой компетентности. Автором доказано, что цифровая компетентность является составной частью профессиональной компетентности будущего учителя. Отмечено, что к элементам рамки цифровой компетентности целесообразно добавить следующие компоненты: мотивация и позитивное самовосприятие, а также внедрение новых методов и приемов формирования цифровой компетентности. Автор делает вывод, что рамка цифровой компетентности охватывает все требования, учитывая процессы реформирования и модернизации образования в Украине, способствуя постоянному профессиональному развитию учителей.

Ключевые слова: цифровая компетентность; подготовка учителей; рамка цифровой компетентности; профессиональное развитие; цифровые технологии; новые методики.

Матеріали надійшли до редакції 19.11.2018 р. 